\title{
PERLINDUNGAN HUKUM TERHADAP WARGA NEGARA ASING KORBAN TINDAK PIDANA PENIPUAN DAN PENGGELAPAN SEWA MENYEWA TANAH
}

\author{
I Wayan Ari Subakti, A.A Sagung Laksmi Dewi, Ni Made Sukaryati Karma \\ Fakultas Hukum Universitas Warmadewa, Denpasar-Bali, Indonesia
}

\begin{abstract}
Abstrak
Perlindungan hukum adalah segala upaya pemenuhan HAM serta hal tersebut dipersembahkan pada individu luas supaya setiap orang dapat memperoleh adanya suatu rasa kenyamanan dan ketentraman dalam menjalankan kehidupan tanpa adanya suatu ancaman tertentu yang timbul dari diri masyarakat lainnya, dengan demikian maka masyarakat tidak mengeluh terhadap adanya suatu penegakan peraturan. Pemidanaan yakni suatu proses yang timbul akibat dari adanya suatu ulah yang dilakukan oleh setiap individu, dimana hal tersebut diberikan suatu sanksi yang mengikat. Tujuan penelitian ini adalah untuk mengetahui arti serta komponen dalam tipu-menipu dan penggelapan dan untuk menjelaskan perlindungan hukum terhadap rakyat asing korban perbuatan pidana sewa menyewa tanah. Penelitian ini menggunakan metode hukum normatif. Perbuatan tipu-menipu merupakan suatu perbuatan berdasarkan apa yang diperbuat oleh seseorang menyangkut barang. Unsur-unsur dari tindak pidana penipuan yaitu membujuk orang lain, untuk menyerahkan suatu barang. Sedangkan penggelapan barang merupakan suatu perbuatan yang dapat merugikan seseorang guna untuk menguntungkan diri sendiri. Unsur-unsur dari tindak pidana penggelapan yaitu, barang siapa, suatu barang, seluruhnya atau milik orang lain, yang berada dalam teritorialnya bukan kejahatan, dengan melawan hukum dan dalam sadar. Perlindungan hukum WNA terhadap kejahatan penggelapan dan penipuan sewa menyewa tanah diatur pada Kitab Undang-Undang Hukum Pidana pasal 378 KUHP.
\end{abstract}

Kata Kunci: Perlindungan Hukum; Tindak Pidana; Penipuan; Penggelapan; Warga Negara Asing

\begin{abstract}
Legal protection is all efforts to fulfill human rights and it is offered to the broad individual so that everyone can get a sense of comfort and peace in running life without a certain threat arising from other societies, thus the community does not complain about the existence of an enforcement the rules. Criminalization is a process that arises as a result of an act carried out by each individual, where it is given a binding sanction. The purpose of this research is to find out the meaning and components in deception and embezzlement and to explain the legal protection of foreign people who are victims of the crime of renting land. This research uses normative legal methods. Deception is an act based on what someone does with regard to goods. The elements of a criminal offense are to persuade another person to hand over an item. While embezzlement of goods is an act that can harm a person in order to benefit himself. The elements of embezzlement are: whoever, an item, all or the other people who are in their territory is not a crime, by fighting the law and being aware. The legal protection of foreigners against evasion and fraud in renting land is regulated in the Criminal Code article 378 of the Criminal Code.
\end{abstract}

Keywords: Legal Protection; Crime; Fraud; Embezzlement; Foreign Citizens

\section{PENDAHULUAN}

Tanah adalah suatu keperluan yang dapat digunakan oleh seseorang untuk memenuhi suatu keperluan. Setiap individu berkembang dan melakukan setiap kegiatan dengan media tanah, tanah sangat penting didalam menunjang segala sesuatu aktivitas yang dijalankan oleh setiap individu, maka dari itu pentingnya peranan tanah bagi setiap individu. Hak atas tanah, merupakan hak yang didapat sebagai suatu pelengkap adanya pembangunan, dimana setiap individu memiliki aturan kepemilikan pribadinya. Adanya suatu hak tersebut, dimana hal itu sangatlah penting, maka didalam menggunakannya haruslah sesuai dengan prosedur yang telah ditentukan oleh sang penguasa yaitu pemerintah dengan tujuan tertentu, agar dapat meminimalisir sengketa dikemudian harinya. Maka dari itu, adanya suatu prosedur sangat mempengaruhi terhadap suatu perkembangan hak yang dimiliki oleh seseorang di dalam menyelesaikan suatu sengketa. 
Pada aktivitas menyewa, adanya suatu pertikaian jika para pihak melanggar kewajibannya yang satu dengan yang lainnya, sehingga memungkinkan terjadi konflik antara individu satu dengan individu lainnya. Pertikaian menyewa, adalah suatu persoalan yang mudah, dimana setiap keperluan akan hal tersebut semakin hari semakin meningkat, akan tetapi jumlahnya tetap, dilain sisi adanya suatu peningkatan akan hal tersebut. Adanya kesulitan terhadap rakyat asing untuk memperoleh tanag, menimbulkan opsi lain terhadap rakyat asing dengan cara bekerja sama dengan warga setempat. Sehingga peluang bisnis dibidang sewa menyewa tanah bagi warga setempat semakin menjanjikan, namun ternyata masih banyak yang memanfaatkan peluang tersebut untuk melakukan kejahatan, yang dimana hal tersebut sewaktu-waktu dapat merugikan suatu negara ataupun individu satu dengan individu lainnya, maka sangat diperlukan adanya aturan akan hal tersebut agar tidak terulang kembali. Dengan demikian, terjadinya suatu perbuatan melawan aturan di derita oleh WNA dengan berbagai macam modus sehingga mengakibatkan kerugian secara materiil dan inmateriil. Warga Negara Asing (WNA) yaitu, orang yang tinggaI dan berinteraksi di wilayah tertentu di suatu neagra tapi tidak terdaftar di negara itu atau bisa dikatakan orang asing adalah orang yang bukan warga negara Indonesia.

Pelaku melakukan perbuatan melawan hukum ini dikarenakan faktor sosial dan faktor ekonomi yang begitu berat, sehingga pelaku melakukan perbuatan yang dapat merugikan seseorang yang dimana suatu kerugian itu dapat berupa kerugian materiil dan inmateriil. Hal tersebut merupakan satu alternative pemberantasan perbuatan melawan aturan, maka aturan pidana yaitu "kebijakan kriminal". Aturan atau pemberantasan perbuatan melawan aturan pada dasarnya merupakan suatu upaya untuk menegakan keadilan serta mewujudkan apa yang dicita-citakan oleh setiap individu (Arief 2008).

Dari berbagai ancaman delik yang terjadi di masyarakat saIah satunya adaIah meIawan hukum tindak pidana penipuaan dan penggelapan, bahkan daIam masa ini banyak terjadi delik tersebut, dan penggelapan dengan bermacam bentuk yang terus berkembang yang menuju semakin tinginya intelektualitas dari delik penipuan dan penggelapan. Adapun kasus yang terkait dengan tindak pidana penipuan dan penggelapan yang diangkat penulis adalah tindak pidana penipuan dan penggelapan yang dilakukan oleh terdakwa I Wayan Selamet yang kedudukannya sebagai pemilik tanah dan Kumi Kikuchi (WNA) sebagai penyewa tanah. Rumusan masalah pada penelitian ini adalah bagaimanakah arti serta komponen dalam tipu-menipu dan penggalapan? Dan bagaimanakah perlindungan hukum terhadap warga negara asing korban perbuatan pidana sewa menyewa tanah? Berdasarkan rumusan masalah tersebut, tujuan penelitian ini adalah untuk mengetahui arti serta komponen dalam tipu-menipu dan penggelapan dan untuk menjelaskan perlindungan hukum terhadap rakyat asing korban perbuatan pidana sewa menyewa tanah.

\section{METODE PENELITIAN}

Penelitian ini dirancang dengan menggunakan metode hukum normatif. Beranjak dari metode ini, pendekatan yang digunakan pada penelitian ini ialah pendekatan perundang-undangan (statute approach), pendekatan konsep (conceptual approach), dan pendekatan kasus (case approach). Bahan hukum yang digunakan terdiri dari bahan hukum primer, bahan hukum sekunder, dan bahan hukum tersier. Metode pengumpulan bahan hukum adalah dengan studi kepustakaan. Teknik pengumpulan bahan hukum, ialah dengan cara mempelajari literatur dan penelitian serupa.

\section{HASIL DAN PEMBAHASAN}

Hukum merupakan kumpuIan aturan yang berIaku di kaIangan masyarakat yang dimana untuk mengatur ketentraman dan ketertiban dalam kemasyarakatan yang meliputi Iembaga-Iembaga dan proses guna menajaIankanya (Najih 2012). Perlindungan hukum adaIah segaIa Tindakan yang diberikan oIeh suatu badan hukum untuk memberikan jaminan dan keamanan dari delik yang mengancam jiwa orang tersebut daIam berbagai bentuk jaminan yang diberikan untuk keamanan orang tersebut.

Soedarto mengatakan bahwa hukum pidana merupakan sistem sanksi yang negatif, ia diterapkan, jika cara Iain sudah tidak dapat diseIesaikan lagi, bagaimanapun juga diberikan agar memberikan efek jera kepada peIaku dari dideritanya rasa tidak enak atau perbuatan yang merugikan dengan memberikan kurungan untuk memberikan aIasan pembenaran (Prasetyo 2014).

Pemidanaan merupakan bagian penting dari hukum pidana, karena merupakan ujung tertinggi dari keseluruhan proses memberikan ganti rugi yang dibuatnya dengan memberikan kurungan yang setimpaI. Dengan demikian, konsepsi tentang kesalahan mempunyai pengaturan yang signifikat terhadap pengenaan pidana dan proses pelaksanaannya merupakan perwujudan dari celaan tersebut 
(Huda 2016). Menurut Cleiren bahwa tindak pidana penipuan adalah tindak pidana dengan adanya akibat (gevolgsdelicten) dan tindak pidana berbuat (gedragsdelicten)atau delik komisi (Hamzah 2010).

Sarana perlindungan Hukum ada dua macam (Hadjon 2007), yaitu :

1. Sarana Perlindungan Hukum Preventif

Pada perlindungan hukum preventif ini, orang dapat memberikan nota keberatan sebelum adanya putusan yang diberikan dari pemerintah. Tujuannya adalah mencegah terjadinya sengketa. Perlindungan hukum preventif sangat besar artinya bagi tindak pemerintahan. Di indonesia belum ada pengaturan khusus mengenai perlindungan hukum preventif.

2. Sarana Perlindungan Hukum Represif

Perlindungan hukum yang represif bertujuan untuk menyelesaikan sengketa. Penanganan perlindungan hukum oleh Pengadilan Umum dan Pengadilan Administrasi di Indonesia termasuk kategori perlindungan hukum ini. Prinsip perlindungan hukum bertumpu kepada hak manusia dan adanya prinsip negara hukum. Dikaitkan dengan pengakuan dan perlindungan terhadap hak-hak asasi manusia, pengakuan dan perlindungan terhadap hak-hak asasi manusia mendapat tempat utama dan dapat dikaitkan dengan tujuan dari negara hukum. Perlindungan hukum yang mengkhusus bagi warga negara asing di Indonesia memang belum ada, tetapi menurut (Prodjodikoro 2008) ada beberapa prinsip terkait keberlakuan hukum pidana di Indonesia, yaitu:

a. Prinsip Teritorialitas

Prinsip teritorialitas adalah prinsip yang menganggap hukum pidana Indonesia berlaku di dalam wilayah Republik indonesia, siapapun yang melakukan tindak pidana.

b. Prinsip Nasional aktif

Prinsip ini dianut dalam Pasal 5 (KUHP) yang mengatakan bahwa ketentuan- ketentuan hukum pidana lndonesia berlaku bagi warga negara Indonesia yang melakukan tindak pidana di luar wilayah negara lndonesia.

c. Prinsip Nasional pasif

Prinsip ini memperluas berlakunya ketentuan-ketentuan hukum pidana Indonesia di luar wilayah Indonesia berdasar atas kerugian nasional amat besar.

d. Prinsip Universalitas

Prinsip ini melihat pada suatu tata hukum internasional, dimana terlibat kepentingan bersama dari semua negara di dunia.

Warga negara adalah penduduk negara atau bangsa berdasarkan keturunan, tempat kelahiran, dan sebagainya, yang memiliki hak dan kewajiban secara penuh sebagai warga negara tersebut, dapat digolongkan negara asli dan Warga Negara Asing (WNA). WNA merupakan orang yang tinggal dalam suatu wilayah tersebut yang mana ia melakukan kepentingan dalam beberapa waktu tertentu yang mana tidak menetap di suatu negara tersebut namun tidak juga terdaftar tinggal secara lama, meskipun memiliki status WNA namun mendapatkan hak dan kewajiban yang sama di Indonesia.

Menurut Lamintang, delik penggelapan adalah penyalahgunaan hak atau penyalahgunaan rasa tanggungjawab yang diberikan oleh seorang yang mana kepercayaan tersebut diperolehnya tanpa adanya unsur melawan hukum. Menurut beliau, dengan penyebutan penyalahgunaan hak atau penyalahgunaan kepercayaan akan memberikan pengetahuan yang mana perbuatan yang dilarang dan hukuman yang setimpal apa saja yang diberikan (Lamintang 1989).

Penggelapan adalah kejahatan yang hampir sama dengan pencurian dalam pasal 362 KUHP. Bedanya ialah pada pencurian barang yang dimiliki itu belum berada di tangan pencuri dan masih harus "diambilnya" sedangkan pada penggelapan waktu dimilikinya barang itu sudah ada di tangan si pembuat tidak dengan jalan kejahatan (Soesilo 1984).

Menurut Tongat, dengan berdasarkan Pasal 372 KUHP, bahwa tindak pidana penggelapan dalam bentuk pokok mempunyai unsur sebagai berikut:

a. Unsur-unsur objektif yang terdiri dari (Tongat 2003):

1) Barang siapa,

Unsur barang siapa memacu kepada peIaku antara lain manusia dan koorporasi, menunjuk subjek hukum itu, baik orang maupun badan hukum jika melakukan delik dapat dikatakan sebagai pelaku dari suatu delik tersebut bila terbukti dengan jelas melakukan suatu kejahatan dengan disengaja.

2) Sesuatu, barang, 
Barang memiliki arti yang luas baik bergerak maupun non bergerak sampai keciri-ciri yang lebih spesifik lagi.

3) Seluruhnya milik orang lain,

Sesuatu benda berada dalam kekuasaan seseorang adalah apabila antara orang itu dengan bendanya terdapat hubungan yang sedemikian eratnya, sehingga apabila ia akan melakukan segala perbuatan terhadap benda itu ia dapat segera melakukannya secara langsung dan nyata, tanpa terlebih dulu harus melakukan perbuatan lain. Benda milik orang lain berada dalam kekuasaan seseorang bukan karena kejahatanlah yang merupakan unsur dari delik penggelapan ini, dan ini dapat terjadi oleh sebab perbuatan- perbuatan hukum seperti: penitipan, perjanjian sewa menyewa, pengancaman, dsb (Chazawi 2009).

4) Secara melawan hukum,

Bahwa, unsur lain yang terdapat pada Pasal 372 KUHP, yaitu unsur "melawan hukum mengaku sebagai milik sendiri barang sesuatu yang seluruhnya atau sebagian adalah kepunyaan orang lain".

Bahwa, maksud unsur "melawan hukum" adalah apabila perbuatan yang dilakukan oleh seorang pelaku atau dader bertentangan dengan norma hukum tertulis Per-UU-an atau norma hukum tidak tertulis (layak dan selaras) atau konflik dengan hak orang lain sehingga dikenakan hukuman setimpal.

Kejahatan adalah prilaku yang dilarang oleh aturan yang beriaku, larangan tersebut dibarengi dengan hukuman yang setimpal dengan perbuatan yang dilakukan, hukuman yang setimpal yang diberikan adalah bagian dari hukum yang memberikan efek jera kepda si pelaku itu, hukumaan diberikan untuk mewujudkan keselarasan dalam masyarakat guna mencapai kedamaian untuk mengontrol agar meminimalisir terjadinya suatu kejahatan dan untuk merehab pelaku untuk tidak mengulang kembali kejahataanya.

Aturan hukum yang berlaku untuk mengatur masyarakat, baik dalam lingkungan yang kecil maupun dalam lingkungan yang lebih besar, agar didalamnya terdapat suatu keserasian, suatu ketertiban, suatu jaminaan, dan lain sebagainya. Kurungan merupakan yang sangat berarti dari hukum pidana, dikarenakan kunci dari keseluruhan pertanggung jawaban seseorang yang telah bersalah melakukan kejahataan. Hukum pidana tanpa kurungan berarti memberikan kesalahan bagi orang lain namun tidak diberikan kejeraan. Pemidanaan diberikan karena si pelaku diharuskan menerima sanksi dari perbuatan yang dilakukan demi kesalahannya. Kurungan menjadi solusi yang adil bagi kecerobohan dilakukan.

Tindak pidana penipuan dan penggelapan merupakan tindak pidana yang berhubungan dengan moral maupun mental manusia serta kepercayaan dan kejujuran seseorang. Tindak pidana penipuan dan penggelapan ini perbuatan yang dilakukan dengan sadar dan melawan hukum yang ada. Sesuai dengan bunyi pasal 372 KUHP, pelaku tindak pidana penggelapan dapat dijatuhi pidana kurungan paling lama 4 tahun dan denda uang sebesar sembilan ratus ribu rupiah. Penyebab seseorang melakukan tindak pidana penipuan dan penggelapan adalah karena adanya wanprestasi. Wanprestasi berasaI dari bahasa BeIanda, keIaIaian sengaja. Wanprestasi memiliki arti sengaja tidak memenuhi suatu perjanjian. Sehingga sanksi yang dapat diberikan kepada pelaku tindak pidana penipuan dan penggelapan dalam sewa menyewa tanah ada 2, apabila dilihat dari sanksi hukum perdata maka sanksinya berupa kewajiban untuk memenuhi prestasi, pembayaran ganti rugi materiil dan pembayaran ganti rugi immateriil. Sedangkan apabila dilihat dari sanksi hukum pidana maka pelaku dapat dikenakan pasal 378 KUHP tentang Penipuan dan pasal 372 tentang Penggelapan dengan bentuk sanksi berupa hukuman penjara dan hukuman denda.

\section{SIMPULAN DAN SARAN}

\section{Simpulan}

Berdasarkan uraian diatas, simpulan yang dapat diberikan ialah, pengertian dan unsur-unsur tindak pidana penipuan dan penggelapan ialah sebagai berikut, penipuan adalah perlakuan atau omongan bukan kebenaranya, palsu dan dengan inisiatif untuk mengelabuhi, mengakali atau memperkaya pelaku. Unsur-unsur dari tindak pidana penipuan yaitu membujuk orang lain, untuk menyerahkan suatu barang. Penggelapan adalah kejahatan yang hampir sama dengan pencurian hanya saja waktu dimilikinya barang itu sudah ada di tangan si pembuat tidak dengan jalan kejahatan. Unsur-unsur dari tindak pidana penggelapan yaitu, barang siapa, suatu barang, seluruhnya atau milik orang lain, yang berada daIam teritorialnya bukan kejahatan, dengan melawan hukum dan dalam sadar. 
Perlindungan hukum WNA terhadap kejahatan penggelapan dan penipuan sewa menyewa tanah didapatkan melalui Kitab Undang-Undang Hukum Pidana, pelaku tindak pidana penipuan dikenakan pasal 378 KUHP yang dapat dijatuhi pidana penjara paling lama empat tahun, dan pelaku tindak pidana penggelapan dikenakan pasal 372 KUHP yang dapat diberikan kurungan selama empat tahun dan denda materiil sebesar sembilan ratus rupiah. Warga negara asing yang menjadi korban tindak pidana penipuan dan penggelapan berhak mendapatkan perlindungan hukum sesuai dengan ketentuan Undang-Undang Nomor 31 Tahun 2014 tentang Perlindungan Saksi dan Korban.

\section{Saran}

Apabila dalam melakukan suatu perjanjian sewa-menyewa tanah, sebaiknya untuk selalu waspada, jangan dengan mudah percaya, ditambah lagi dengan perbedaan kewarganegaraan yang mana itu akan mempersulit proses perjanjian, sebaiknya menuangkan perjanjian tersebut dalam bentuk akta otentik untuk menghindari adanya konflik di kemudian hari akibat adanya wanprestasi dalam proses sewa menyewa tanah.

Sebaiknya dibuatkan ketentuan-ketentuan yang mengatur tentang perlindungan hukum bagi warga negara asing di Indonesia agar warga negara asing mengetahui bahwa ia dan hak-haknya dilindungi di Indonesia. Serta untuk meminimalisir tindak pidana yang terjadi terhadap warga negara asing di Indonesia.

\section{DAFTAR PUSTAKA}

Arief, Barda Nawawi. 2008. Bunga Rampai Kebijakan Hukum Pidana. Jakarta: Kencana Prenada Media Group.

Chazawi, Adami. 2009. Hukum Pidana II. Depok: Raja Grafindo Persada.

Hadjon, Philipus M. 2007. Perlindungan Hukum Bagi Rakyat Di Indonesia, Sebuah Studi Tentang Prinsip- Prinsipnya, Penanganannya Oleh Pengadilan Dalam Lingkungan Peradilan Umum Dan Pembentukan Peradilan Administrasi. Jakarta: Peradaban.

Hamzah, Andi. 2010. Delik-Delik Tertentu (Speciale Delicten) Di Dalam KUHP. Jakarta: Sinar Grafika.

Huda, Chairul. 2016. Dari Tiada Pidana Tanpa Kesalahan Menuju Kepada Tiada Pertanggungjawaban Pidana Tanpa KesaIahan. Jakarta: Kencana Prenada Media.

Lamintang. 1989. Delik-Delik Khusus Kejahatan-Kejahatan Terhadap Harta Kekayaan. Bandung: Sinar Baru.

Najih, Mokhammad. 2012. Pengantar Hukum Indonesia. Jakarta: Setara Press.

Prasetyo, Teguh. 2014. Hukum Pidana. Jakarta: Rajawali Pers.

Prodjodikoro, Wirjono. 2008. Tindak-Tindak Pidana Tertentu Di Indonesia. Bandung: Refika Aditama. Soesilo. 1984. Pokok-Pokok Hukum Pidana Peraturan Umum Dan Delik-Delik Khusus. Bogor: Politea. Tongat. 2003. Hukum Pidana Materiil. Malang: Umm Press. 